\title{
Language Situation in Ripky (Chernihiv): Results of Focus Group Research
}

\author{
Salvatore Del Gaudio \\ Borys Hrinchenko Kyiv University
}

\begin{abstract}
This article highlights the results of recent focus group interviews about language use carried out in the small town of Ripky and in nearby rural villages. Ripky and environs are situated in the northwestern part of the region of Chernihiv in central northern Ukraine. This research complements a more extensive study devoted to the analysis of the language situation of this area that attempted to obtain a deeper understanding of the language attitudes (including covert ideology) of this administrative district. This territory is interesting from dialectal and sociolinguistic viewpoints, as several language varieties coexist. This is also a consequence of the geographic proximity of the three main east Slavic countries: Ukraine, Belarus, and the Russian Federation. The qualitative data obtained from four focus groups in the local secondary school of Ripky are of particular significance because they clarify the language/dialect selection of the speaker, thus adding information to the previously outlined framework of the peculiar language situation in this district.
\end{abstract}

Keywords: focus group, language situation, Ripky (Chernihiv), Ukrainian, Russian, Belarusian.

\section{INTRODUCTORY REMARKS}

$\mathbf{T}$

his article continues a series of studies devoted to the language situation in the district of Ripky, a small town in Ukraine: this includes the urbantype settlement of Ripky per se, which is also the main administrative centre of the Ripky district, ${ }^{1}$ and its surrounding rural areas. The Ripky district is situated in the northwestern part of the region of Chernihiv (Ukraine). This administrative unit borders the region of Homel in Belarus and is not far from the Russian Federation. Information derived from the interviewees that made up the four mini focus groups presented below complements my more extensive contribution to an analysis of the language situation in Ripky and its rural areas (Del Gaudio, "Language Situation").

The study of the language situation in Ripky and its rural environs included the following interrelated aspects ${ }^{2}$ : language selection, language

\footnotetext{
${ }^{1}$ Ukr. "raionnyi tsentr."

${ }^{2}$ A parallel aim is to enhance the sociolinguistic framework in order to integrate specific dialectal research.
} 
distribution, relationship between local dialect $(s)^{3}$ and the standard languages spoken along the borders (Ukrainian, Belarusian, and Russian), and a perceptual characterization of the local dialect(s) in connection with the Ukrainian-Russian-(Belarusian) mixed speech, "Surzhyk."4

My previous research ${ }^{5}$ demonstrates that language selection and distribution in this area may be composed of an array of language varieties that differentiate it from other southern districts of the same region or from other regions of central Ukraine. Here, besides the coexistence of typical Ukrainian Russian bilinguism ${ }^{6}$ and forms of mixed speech and local dialect(s), Belarusian language varieties have historically affected both the traditional local dialects and the mixed speech based on them.

Apart from the specificity of the local dialect(s) under linguistic analysis, which are basically spoken in traditional form by an always decreasing number of speakers of the older generations (65-90 years old), most respondents in previous research also used the above-mentioned mixed speech, along with regionalized varieties of Ukrainian and Russian. The figures obtained in a concomitant study clearly demonstrate that about $50 \%$ of respondents (from all age ranges) claimed to speak dialect in everyday life. The language options of the other half of respondents revealed a more complex picture (Del Gaudio, "Language Situation").

The awareness that a mixed code is involved is more typical among middle and younger (14-45 years old) than in older generations. Older individuals were found to adhere more closely to their dialect than younger speakers, and many, in their perceptional description of the local dialect ${ }^{7}$, acknowledged that it was also similar to Belarusian (as shown by my current and previous research). It also emerged that middle generation speakers

\footnotetext{
${ }^{3}$ Although each local dialect presents at its micro-level a minimal degree of variation, one could generally speak of a "dialect" in the singular, if it is considered in its entirety. Such a usage would align with western European dialectal studies. Nevertheless, as mentioned elsewhere, I follow a term used in the East Slavic tradition (see Del Gaudio, “Ukrainsko-russkaia smeshannaia rech'”).

4 The use of quotation marks around "Surzhyk" provides evidence of the nonlinguistic origin of the name designating this mixed variety and the fact that the sociolinguistic implications of this term remain, to a certain extent, controversial in the specialist literature. It is worth emphasizing, however, for a non-specialist reader, that the word "Surzhyk" indicates primarily a Ukrainian-Russian mixed code based on Ukrainian with the addition of Russian elements (hybrid derivational forms, lexemes, etc.).

${ }^{5}$ Cf. Del Gaudio, "Between Three Languages" and "Language Situation."

6 I use the term "bilinguism" instead of "bilingualism," more popular in North America.

7 Cf. Preston.
} 
displayed the widest range of language choice: from the "authentic" local dialect (very limited) to a mixed speech.

Young people tended to associate their mixed speech and/or dialect more directly with Ukrainian and Russian, and rarely with Belarusian. It was also noted that younger respondents (14-30 years old) are more likely to speak Russian in most situational contexts. Yet a small but growing minority of well-educated young speakers opts for Ukrainian. Hence, the mini focus groups were organized to gain further insight into young people's/teenagers' language behaviour (selection and use) in the chosen area.

This article is divided into three main sections. The methodological importance of focus group research in accomplishing a sociolinguistic survey is illustrated in section one, where I also present transcriptions of the most essential excerpts of the audio recorded interviews. The elicited data are discussed in section two. Section three provides a commentary about the idiosyncratic features of the language variety used by some of the participants in the focus groups.

\section{Focus Group: MethodologicAl ASPECTS}

The group of people to be interviewed, male and female teenagers (high school students), was chosen on the basis of characteristics relevant to the research. The focus group, where I acted at the same time as a researcher and moderator, took place in the spring of 2018 in the comprehensive school no. 2 of Ripky (Ukr. "Ріпкинська школа № 2"). ${ }^{8}$

The ongoing focus group praxis recommends that teenagers be organized in smaller groups than adults, and that the interviews be shorter than they would be with adults (Smithson 358; Kruger). In this case one can speak of mini focus groups, as the school allowed four interviews with four students at a time. Each interview lasted from 20 to 30 minutes. The number of participants was equally distributed between males and females aged 14 to 16 years.

The topic of discussion was selected beforehand. Only the relevant aspects of the conversations were recorded and will be reported here. I tried to put participants at ease with some small talk before starting the discussion. The students were informed about the purpose of the interview and the reason they were chosen to participate. This was done with the aim

\footnotetext{
${ }^{8}$ I wish to thank once again the school staff who helped and supported me in this individual research. In particular: the school director Serhii Lebedko; the following teachers of Ukrainian: Oleksandr Khololiienko, Tetiana Myn'ko, Tetiana Moroz, and their colleagues.
} 
of breaking down their initial reserve and to gradually introduce them to the topic, thus creating a more relaxed atmosphere. Notwithstanding my efforts and active role, some of the boys appeared to feel somewhat inhibited (or not interested enough in the conversation) and did not speak freely during the elicited discussion. This was particularly true when I switched on the tape-recorder, although I tried to distract them. For this reason the flow of discussion at certain points might resemble more a semistructured interview with a predetermined set of questions than an authentic focus group discussion. Conversely, other participants took a more active role in the conversation, providing me with infomative material.

The answers selected in the focus groups, counterchecked in a second phase with the support of local teachers ${ }^{9}$ of Ukrainian language and literature, completed the informational gaps left open by the questionnaire, ${ }^{10}$ and confirmed some of my previous working hypotheses (cf. Del Gaudio, "Between Three Languages" 83-86, and "Language Situation"). According to these, the entire area, besides an asymmetric Ukrainian-Russian bilinguism, typical for some regions in Ukraine where Ukrainian and Russian cover different functional domains, seems to be characterized by polyglossia. Here, different language codes overlap and/or are selected according to a series of variables summarized below:

1) local dialect(s) and/or micro-dialects;

2) different degrees of mixed speech based on the local dialect(s) with an admixture of Ukrainian, Russian, and Belarusian features (cf. the notion of a "Surzhyk prototype");

3) Ukrainian with local/regional features, i.e., a regional variety of Ukrainian along with contemporary standard Ukrainian;

4) a Ukrainized or "national" variety of Russian, typical of most Ukrainian regions, defined in the specialist literature as UkrainianRussian (U-Russian).

\subsection{Transcript of the Interview Excerpts}

The original questions and answers will be reported, first in Ukrainian (the language of the interview) and second in English. M stands for moderator (interviewer) and P stands for participant. Participants' direct answers are italicized.

\footnotetext{
${ }^{9}$ A discussion about the language situation in this area was separately conducted with local school teachers of Ukrainian.

10 The questionnaire preceded the focus groups. One hundred and fifty questionnaires were distributed in the rural villages belonging to the district of Ripky - where I also collected dialectal data-and in the town of Ripky.
} 


\section{First group: 4 participants ( 2 females +2 males)}

М. Ваша «мова» збігається з «мовою» старих людей? - Does your spoken everyday language coincide with that of old people?

P. Не дуже. - Not really.

М. А ваша місцева говірка містить білоруські елементи, чи вона ближче до української мови? - Does your local dialect preserve some Belarusian elements or is it closer to Ukrainian?

Р. До української. - It is closer to Ukrainian.

M. На вашу думку, це змішана говірка чи говірка i все? - Is it, in your opinion, a mixed dialect or just a local dialect?

Р. Змішана. - Mixed.

M. А старі люди по-інакшому розмовляють? - Do old people speak differently?

P. Різниці є, але не дуже великі. - There are differences, but they are not so great.

М. А Ви якою мовою розмовляєте? - And in which language do you speak?

P. На говіриі. - In dialect.

М. А з друзями в школі? - What about your school friends?

P. Теж! - Same!

М. А з викладачами? - And with the teachers?

P. Українською! - In Ukrainian!

М. А російською взагалі не розмовляєте? Дуже часто чую російську. And you don't speak Russian? I often hear it.

P. Hi! - No!

М. Це не Ви, так? - It's not you, right?

М. А на яку мову більше схожа ваша говірка? На білоруську, на українську чи на російську? - And which language is your local dialect most similar to? Belarusian, Ukrainian, or Russian?

M. Ви інколи розмовляєте змішаною мовою? Суржиковатою? - Do уоu speak sometimes the mixed language? In a surzhyk-like manner?

Р. Так. - Yes.

М. Як ви відрізняєте змішану мову від вашої говірки? Чи для вас це одне і теж? - How do you distinguish the mixed language from your own local dialect? Or is it the same thing?

P. Схожі. - They are similar.

М. Ваша говірка рівною мірою схожа на російську, білоруську та українську? Чи важко судити? - Is your dialect, in the same way, similar to Russian, Belarusian, and Ukrainian? Or is it hard to say?

P. На українську! - To Ukrainian!

P. На російську! - To Russian!

М. А Ви? - And you?

P. Тоже! - Same! 
М. А Ви якою мовою почали говорити у дитинстві? - And which language did you begin to speak in your childhood?

P. На говіриі. - Dialect.

М. Крім говірки, які інші мови Ви вважаєте рідними? - Besides the dialect, what other languages do you consider to be your native?

P. Українську. - Ukrainian.

М. Хто частіше використовує місцеву говірку? - Who speaks the local dialect more often?

P. Чоловики і жінки рівною мірою. - Men and women to an equal extent. В Ріпках, у Чернігові люди розмовляють більше російською. А у селах, ні! Більше говіркою, а я говорю говіркою. - People speak more Russian in Ripky and Chernihiv. But not in the villages! More dialect is spoken there, and I speak dialect.

М. А молоді люди, як Ви? - What about young people like you?

Р. Я більше говіркою. - I speak more dialect.

М. По різному буває? Від чого це залежить? - Is there a difference? Which factors influence your choice?

P. Даже не знаю. - I don't even know.

\section{Second group: 4 participants ( 2 males +2 females)}

М. Тобто, про вашу... Якою мовою розмовляєте, Ви сказали? - Which language do you speak, you said?

P. На суржике! - "Surzhyk"!

М. На основі якої / якого? - On which base?

P. Украӥнський (украӥнською), руський (російською), білоруський (білоруською). - On the basis of Ukrainian, Russian, and Belarusian.

M. I молоді люди усі так говорять у Ріпках? - Do all young people speak like you?

Р. Є такі на украӥнській мові, є на руській. $Є$ смесь, я не знаю... - No, some speak Ukrainian; some Russian. There is a mix, I don't know...

M. А старі люди ще розмовляють говіркою? - Do old people still speak dialect?

Р. Да! - Yes, they do. (М. А молоді вживають її менше. - Whereas younger people use it less).

М. А я на вулиці чую часто російську мову. У Ріпках більше російська мова? - I hear quite often Russian on the streets. More Russian is spoken in Ripky?

Р. Да! В Ріпках більше (російська). Це связана (пов'язано) з тим, що рядом Біларусь і російська границя з Черніговим. Yes! In Ripky Russian is more widely spoken. This can be explained by the fact that Belarus is close by and the Russian border is near Chernihiv. 
М. Але більше молоді люди розмовляють російською, так? А старі люди менше. - Russian is more frequent among younger people, isn't it? Whereas old people speak it less.

Р. Да! - Yes!

М. А у вас у селі, як там? - What about your village, how is it there?

Р. Більш теж суржиком. - Also, more "Surzhyk."

М. Це молоді? - Are they уоung people?

P. Молоді. A старі, дак більш українську мову. - Young people. The old ones, they speak more Ukrainian.

M. Тобто, місцевий діалект, так? Do you mean the local dialect (Ukr. "mistsevyi dialekt")?

Р. Так, місцевий діалект. Yes, the local dialect.

М. Хто частіше розмовляє місцевою говіркою, жінки чи чоловіки? -Who speaks the local dialect more often?

P. Однаково, єслі однаковий «возраст» (вік). - People of the same age tend to speak the same language.

М. Дякую! - Thank you.

\section{Third group: 4 male participants}

М. Яку мову Ви, в основному, використовуєте кожен день? - Which language do you use every day?

P. Суржик. - "Surzhyk."

М. Це на основі російської, української, білоруської чи більше ...? - Is it based on Ukrainian, Russian, and Belarusian, or more...?

P. Це на основі української, російської, білоруської... - It's based on Ukrainian, Russian, and Belarusian.

M. А у містечках де ви живете, це село, молодь як розмовляє? - And in the small towns where you live, it's a village, how does the youth speak?

P. Так само, майже украӥнський. - The same, almost Ukrainian.

M. В школі, на коридорах так само і є російська. А у Ріпках? - At school, in the halls there is also Russian. And in Ripky?

Р. Більше російська. - More Russian.

M. А старі люди розмовляють говіркою? - What about old people, do they speak dialect?

P. Суржик - "Surzhyk."

М. Місцевим діалектом? Чи є у вас різниця між ними? У вас розрізняють місцеву говірку від суржика? У чому полягає різниця, на Вашу думку? Local dialect? Do you differentiate between them? Do you differentiate between the local dialect and Surzhyk? What is the difference, in your opinion?

P. Кожна людина, кожну річ висловує по-своєму. - Each person expresses each thing in his/her own way. 
Р. То як. - It depends.

M. А ваші батьки як говорять? - How do your parents speak?

P. Суржик. - "Surzhyk."

М. Де панує російська мова? - Where does the Russian language prevail?

у Чернігові. - In Chernihiv.

M. Але я помітив, що у транспорті тут по-різному буває. - But I noticed that it varied in public and private transport.

M. А у Чернігові? - And in Chernihiv?

P. Українська і російська. - Ukrainian and Russian.

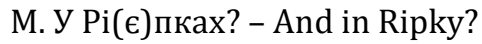

P. Суржик або на російській. - "Surzhyk" or Russian.

М. А у селах? - And in the villages?

P. Українська - Ukrainian.

М. А місцевий діалект для старих людей, да? - And the local dialect for older people, right?

Р. Да. - Yes.

М. Ви відрізняєте суржик від діалекту? - Do уou distinguish "Surzhyk" from just dialect?

P. Так. - Yes.

М. А як...? - Ноw?

P. Hy, це ... проста, так як я щас гавару і так $\epsilon$. - Well, it's ... just, as I'm now talking to you.

Р. Відрізняємо на основі акцента. Зрозуміло, що відрізняється. - Wе differentiate because of the accent. It's clear that there are differences (between the two).

\section{Fourth group: 4 female participants ${ }^{11}$}

М. Якою мовою Ви розмовляєте? - What language do you speak?

P. Змішана мова: українська, російська, білоруська. - Mixed language: Ukrainian, Russian, and Belarusian.

М. Так? А Ви? - Yes, and what about you?

P. Теж змішана з частинками російської мови більше. - Also mixed with more Russian elements (more chunks of Russian).

М. Чи відрізняється, як ви говорите, скажімо так, від говірки людей похилого віку? - Can one distinguish the way you speak, say, from the dialect of the older people?

P. Так, відрізняється. - Yes, one can differentiate it.

М. У чому? - In what way?

\footnotetext{
${ }^{11}$ A real discussion eventually took place with this group of female participants. The most significant facts have been reported here.
} 
Р. Старі люди більш розмовляють ... вони завжди пом'якшують. Наприклад, якщо ми кажемо: мене, тебе..., старші люди кажуть мјеніе, mie(a)біе... - Old people speak more ... they always soften (palatalize). For example, if we say "mene," "tebe" (oblique personal pronouns), old people would say "mienie," "tabie," etc.

M. Ближче до білоруської. Більше білоруських елементів, так? - It is closer to Belarusian. There are more Belarusian elements, right?

М. Чи є дзекання і цекання у старих людей? - Is there "dzekannia" and "tsekannia" in the speech of old people?

Р. Деколи зустрічається. - At times it may come up.

М. Наприклад? - For example?

P. Коли ходжу до бабусі. - When I go to my grandmother.

P. Tjani(e)p - "Tjapier."

Р. Більше українська, а місцевий діалект-(це) для старих людей. - More Ukrainian, and the local dialect-(it is) for the old people.

М. А ви розрізняєте суржик від діалекта? - Can you distinguish between "Surzhyk" and dialect?

P. Tak! - Yes.

М. А як? - How?

Р. Слова, вимова...- Words, pronounciation...

\section{ANALYSIS AND RESULTS OF THE FOCUS GROUPS}

The first focus group, as well as other participants in the following discussions, demonstrated that speakers, in this case young individualswith some exceptions - are not particularly aware of the language variety(ies) they use in daily practice. Their answers were, for the most part, standardized, and tended to adjust to the general flow of the conversation and to other participants' opinions. There was no evidence that participants adopted a critical approach to the topic of discussion. This predictable outcome has been confirmed by the results of questionnaires and oral interviews conducted in this area in the last few years. It seems that the majority of respondents in these questionaires have seldom thought about the characteristics of their local dialect and the degree of similarity it shares with other language varieties typical of this region, such as Ukrainian, Russian, and to a more limited extent, Belarusian (Del Gaudio, "Language Situation").

Except for some straightforward answers concerning (1) the use of "dialect" in everyday conversations, e.g. with family and friends, and (2) the use of Ukrainian with teachers, male participants remained rather vague during the discussion and showed some indifference. They were unable to describe their dialect and to distinguish it from language mixing. At the same 
time, several individuals seemed to imply that their dialect does not contain Belarusian elements, and therefore, they asserted that it is closer to Ukrainian. Nonetheless they also spoke a mixed language with "Surzhyk" traits (cf. Ukr. jargon "surzhykovatoiu").

Parallel dialectal studies carried out in this area have confirmed that the traditional local dialect(s) typically used by older respondents are disappearing, and one can notice a process of convergence toward Ukrainian in language use. On the other hand, the features that these traditional local dialects historically share with southern Russian dialects are reinforced by the strong influence the Russian language exerts in parts of Ukraine, particularly in this border region. The result is a Ukrainian-Russian mixed speech ("Surzhyk") gradually devoid of the typical Belarusian features contained in the traditional dialect.

When asked if they used the Russian language, participants in the focus groups did not answer the question. A hesitancy to openly admit speaking Russian has been noted in most Ukrainian orientated schools over the last two decades. This reluctance was likely intensified by the outbreak of the Russo-Ukrainian military conflict in 2014.

When participants were asked whether their local dialect equally resembles Russian, Belarusian, or Ukrainian, female students indicated Ukrainian and male students indicated Russian as being more similar to the local dialect. This answer is in line with the fact that men tend to prefer Russian (more specifically, a Ukrainized or regional variety of Russian) in daily interactions. ${ }^{12} \mathrm{~A}$ female participant maintained that she used the local dialect more at home (in the village). The focus groups indicated that Russian is more widespread in Ripky (the district centre) than in the small villages in the district.

Participants in the second focus group appeared to be more aware of the language variety they use in daily communication. The most salient aspect of this conversation consisted in the clear answer of a female participant who claimed to basically speak dialect. She also admitted that Russian is quite widespread in the town of Ripky and in Chernihiv (main regional centre). ${ }^{13}$ However, she could not explain the factors that determine or condition her language choice.

At the question about the language mix ("Surzhyk"), all participants agreed that the latter contains Ukrainian and Russian as well as Belarusian elements. Here, "Surzhyk" is to be understood as a more traditional form (variety) of language mix, lightly differentiating itself from the traditional local dialect(s); it still contains evident dialectal (and Belarusian) features,

\footnotetext{
12 This statement relies on participant observation and more recent data that are still under analysis.

13 On this point, see Del Gaudio, "An Outline."
} 
but the process of convergence toward Ukrainian and Russian is evident (cf. the concept of "prototype Surzhyk"14).

When asked whether all young people speak in a similar way, male participants said that language selection depends on various factors: there are those who use Ukrainian, those who speak Russian, and there exists a mixed code. At the direct question whether old people still speak dialect, the unanimous answer was affirmative. When the moderator noted that one can often hear Russian on the streets of Ripky, participants agreed, remarking that the district of Ripky is situated on a crossroad of different borders: Ukraine, Belarus, and Russia. Participants in the focus group somewhat reluctantly admitted that Russian remains the most frequent language option among younger people, especially in the town.

Male participants likewise observed that mixed speech is also widely spoken in the villages among younger generations and agreed that older people speak more "Ukrainian."15 When asked whether they meant the local dialect (Ukr. "mistsevyi dialekt"), their univocal answer was confirmatory. One participant stated, "people of the same age tend to speak the same language."

The third focus group was made up of four male participants. All participants clearly indicated that they used "Surzhyk" to communicate, specifying that their idiom is based on Ukrainian, Russian, and Belarusian. Again, the dominance of Russian in Ripky and Chernihiv was explained by the proximity of these two towns to the state borders. During this discussion the male students admitted that the language mix ("Surzhyk") is more typical of the younger generations, whereas older people speak more "Ukrainian."16 As one participant hesitated before using the word "Ukrainian," the moderator suggested the term "local dialect" instead of "Ukrainian." The participants seemed to agree (non-verbal communication). Some respondents demonstrated a degree of resistance to giving labels to the language varieties they used. Whether the avoidance in naming the language variety stemmed from a lack of critical thinking about language or from a fear of saying something "ideologically" incorrect was unclear. However the first option appears to be more plausible.

Also in focus group three, the participants identified Ukrainian as their native language. Nevertheless, they all acknowledged that different language codes-Ukrainian, Russian, and a language mix (they omitted the word "Surzhyk")—could be observed in their district: young residents use the

\footnotetext{
14 See Del Gaudio, On the Nature of Suržyk 19-20.

15 Here, as underlined in previous studies, the word "Ukrainian" is to be interpreted rather as a traditional, local vernacular; almost as a synonym of a Ukrainian dialectal variety.

16 See the note above.
} 
same kind of speech, both in Ripky and in the neighbouring villages. Outside classroom hours, students also use a mixed speech or, alternatively, Russian. All people tend to stick more to the local way of speaking. The participants confirmed that on the streets of Ripky, drivers and shop assistants often speak Russian (or a regional variety of Russian).

When asked about the language spoken by the older generation, the participants confirmed the use of the local dialect. In the villages (included in the Ripky administrative district), however, "Surzhyk" prevails among young people, and the local dialect is used by older residents. Participants ignored the question regarding the frequency in the occurrence of dialect. They claimed, hesitantly, that the use of dialect was distributed equally among males and females. This finding is in line with the data obtained in previous questionnaires (Del Gaudio, "Language Situation").

Participants claimed that the languages mostly spoken in Ripky and Chernihiv are Russian and Ukrainian, with a prevalence of the former; in Ripky, "Surzhyk" is used in addition to Russian and Ukrainian. The local dialect is much more frequently used in the rural villages of the administrative district of Ripky. The participants said that they were able to differentiate the local dialect from "Surzhyk," but had evident difficulties in describing the difference when this point was raised. They all agreed that older people's speech contained a number of Belarusian elements. They noted that their parents' generation, as assumed a priori, speaks in a mixed way. To sum up, Russian tends to predominate in Chernihiv, and partially in Ripky where mixed speech is also common, although speakers might use Ukrainian in daily conversation. The local dialect is prevalent in the small rural communities and it is perceived by younger speakers as being similar to Ukrainian.

Participants eventually spoke of a different "accent" 17 in the speech of the older people. They also maintained that they could differentiate the dialect from "Surzhyk" on the basis of phonetic features. Eventually, they generally spoke of a different "accent" in the speech of the older people. Here the term "accent" needs to be reinterpreted as the phonetic level. In simple words they can differentiate the dialect from "Surzhyk" on the basis of phonetic features.

Similarly the four female participants in the fourth focus group described their mixed language as being based on Ukrainian, Russian, and Belarusian. ${ }^{18}$ "We speak a mixed language ("zmishana mova") based on Ukrainian, Russian, and Belarusian." These female participants, who showed a high degree of language consciousness, claimed to be able to distinguish

\footnotetext{
17 Here the term "accent" comprises the phonetic-phonological level.

18 Only the most significant parts of the discussion have been reported.
} 
between the local dialect and mixed speech ("Surzhyk") mainly on phonetic and lexical grounds ("pronounciation and words").

They supplied the moderator with some pertinent examples ${ }^{19}$ of the difference between the local (traditional) dialect(s) and the mixed language ("Surzhyk"). The examples given were lexemes typical of the local dialect (and shared by adjacent Belarusian dialects): pronouns and adverbs. The correctness of some of their examples has been confirmed by parallel dialectal studies.

The observation that young people's speech tends more toward Ukrainian and Russian than Belarusian was relevant, confirming that a language levelling toward Ukrainian and Russian has been underway in Ripky and its rural environs over the last three or four decades. The participants likewise confirmed the sporadic occurrence of phonetic features typical of Belarusian, such as "dzekannia" and "tsekannia," in the northern districts of the region of Chernihiv. ${ }^{20}$ Finally, participants agreed that:

1) Russian predominates in Chernihiv;

2) the mixed speech tends to be more common in Ripky;

3) the traditional local dialect with Belarusian elements is more typical in the rural villages of the district of Ripky.

The last part of this active debate was continued in Russian because some of the participants spontaneously switched to this language.

\section{REMARKS ON THE LANGUAGE OF PARTICIPANTS}

A few deviations from the standard Ukrainian language are noticeable in the variety spoken by some of the participants, especially among those who took part in the first and second focus groups. The most evident features concern adverbs and particles: "dazhe nе zпаіи" ("даже не знаю") was used instead of the standard Ukrainian "navit' ne znaiи" ("навіть не знаю"), "tozhe" ("тоже") was used instead of "tezh" ("теж"); the affirmative particle "da" (" $\partial a^{\prime \prime)}$ was used instead of "tak" ("так"); the prepositions and conjunctions "dak" ("дак"), "iesli" ("єслі"); the nouns "smes"' ("смесь"), "vozrast" ("возраст"); the verbs "sviazana" ("связана") with "akannia," and the voiceless [s] as used in Russian instead of " $z v^{\prime \prime}$ 'іаzапо" ("зв'язано") or the

19 The given examples mainly concern the phonetic realization of some specific personal pronouns and adverbs typical of these local dialects, such as "mienie," "tiebie/tabie," "tiapier," as well as single lexical items.

${ }^{20}$ My recent linguistic analysis-still underway-of the typical dialectal features in this territory shows spotty traces of "tsekannia" and rarer cases of "dzekannia." 
more appropriate "роv"iazanо" ("пов'язано"). In colloquial nonstandard Ukrainian, for example, the adverb "tozhe" replaces "tezh" cross-regionally in central nothern Ukraine; the affirmative word for yes - " $d a$ " - is largely used even in cultivated Ukrainian speech, not only in the area of Chernihiv but also in Kyiv. Older generation speakers prefer the nonstandard conjunction "iesli" to "iakshcho." The conjunction "dak" (meaning thus, so, or similarly) is, instead, a typical dialectism of the Polissian area. In the case of the nouns "smes"' and "vozrast," one can synchronically speak of Russian words in Ukrainian. Nevertheless, it should be underlined that these are the only variants speakers use at a regional-dialectal level.

Worthy of note are the colloquial syntactic constructions that are expressed according to the language a person speaks: "na ukrains'kii movi" ("на українській мові"), "па rosiis'kii" ("на російській”), "na hovirtsi" ("на говірці"). The recommended contemporary Ukrainian standard prescribes the instrumental case without preposition when referring to the language a person speaks: "ukrains'koiu movoiu," "rosiis'koiu movoiu." Today, the former constructions are considered to be syntactic calques based on the Russian language: "na russkom iazyke," "na ukrainskom iazyke."

All the elements noted above, along with authentic hybrid morphemes, mixed syntactic chunks, and genuine Russian lexemes and expressions, form the language mix known as Ukrainian-Russian "Surzhyk." This is confirmed by the perception of those contemporary Ukrainian speaker who do not have a solid linguistic (language historical and dialectological) background. Nevertheless, at a deeper level of diachronic and synchronic analysis (which is not discussed here), most of the reported items are typical of many Ukrainian dialectal, historical, and colloquial varieties in large areas of central northern Ukraine. The formal coincidence of these elements with Russian does not necessarily imply a clear-cut differentiation between Russian and Ukrainian. This mixed code, in fact, often functions as a "roofterm," gathering, besides authentic hybrid and Russian elements, a high number of nonstandard (substandard) Ukrainian forms: colloquialisms, dialectisms, archaisms, etc., typical of certain dialectal continua. ${ }^{21}$

\section{CONCLUSION}

The mini focus groups mostly confirmed my previous results regarding the language situation in Ripky and its surrounding rural areas. Standard Ukrainian, for example, is basically spoken by a (gradually growing) minority (post-graduates and professionals) of local speakers in the age

21 On this point, see Del Gaudio, On the Nature of Suržyk and “The Concept of 'Dialect.'” 
range of 23-28 years. Its use is connected with a series of variables such as education, age, profession, and level of mobility.

Even the inteviewees admitted that younger school teachers, doctors and, to a certain extent, public servants speak standard Ukrainian more often than in the past. At the same time, most of the focus group participants seemed to be reluctant to acknowledge the use of Russian. The question of Russian language use often had to be suggested by the moderator, as this information was not volunteered by the students. This attitude toward the Russian language could be explained by a more or less conscious ideological stance engendered by the events of 2013-14 (the Euromaidan/the Revolution of Dignity; Russia's annexation of Crimea, etc.), or more simply by the pro-Ukrainian orientation of the school the students attended.

Russian (with local and regional features, cf. the concept of UkrainianRussian, or U-Russian), however, remains the language of everyday semiofficial communication in the town of Ripky and, to a more limited extent, in the local rural communities. Russian prevails as the main language of interaction among adults of the middle generations (35-50 years old). It is largely spoken in local transport, with foreigners, or along the state borders as a lingua franca of the "East Slavic People." On the other hand, in the small rural communities scattered around the district centre and along the Ukrainian-Belarusian political border, the traditional local dialect(s) and different forms of language mix are recurrent, particularly among respondents from the middle-age group and older generation (50-90 years old).

The focus groups demonstrated that most of the Ripky locals have a confused perception about "what is to be understood as the local dialect" and show evident difficulties in describing and differentiating the local dialect from language mix. Most people of the middle-younger generations tend to define their local vernacular simply as "Surzhyk." However, when the participants in the focus groups were asked to characterize/differentiate their speech from the variety spoken by older people, some of the more language-conscious participants, on the basis of specific examples, tried to draw a line between their spoken variety and the language of older generations. This distinction concerned the phonetic level (e.g., articulation/pronunciation of vowels, consonants, and diphthongs) and the lexical levels.

This study showed that young people in the district of Ripky associate their speech with Ukrainian and Russian more than with Belarusian. The Belarusian elements, i.e., the traits that the traditional local dialect(s) share with the corresponding Belarusian dialects, were rarely noted by participants in the focus groups, suggesting that the everyday nonstandard speech of younger generations is undegoing a process of steady convergence toward Ukrainian and Russian. This finding confirms my previous personal 
observations and is supported by more recent data (Del Gaudio, "Zwischen" 48,51 ). This implies, from a dialectological viewpoint, the elimination of the original Belarusian features from their local varieties. Alternatively, from a social and psychological point of view, this can be also explained as a reduced awareness of the features being called "Belarusian" or as a rejection of this definition for the ever decreasing number of such shared features.

\section{Works Cited}

Del Gaudio, Salvatore. "Between Three Languages, Dialects and Forms of Mixed Speech: Language and Dialect Contacts in Ukrainian-Belarusian Transitional Area." Contributi italiani al XVI Congresso Internazionale degli Slavisti (Belgrado, 20-27 agosto 2018), edited by Laura Salmon et al., Firenze UP, 2018, pp. 79-93.

---. "The Concept of 'Dialect' in the East Slavic Tradition and in Western European Languages." Aktual'ni problemy ukrains'koi linhvistyky. Teoriia i praktyka./Actual Issues of Ukrainian Linguistics: Theory and Practice, vol. XXIX, 2015, pp. 7-20.

---. "Language Situation in the District of Ripky (Černihiv)." Russian Linguistics, vol. 44, no. 2, 2020, pp. 177-201. DOI: 10.1007/s11185-020-09226-x.

---. On the Nature of Suržyk: A Double Perspective. Otto Sagner, 2010. Wiener Slawistischer Almanach, Sonderband 75.

---. "An Outline of the Language Situation in Černihiv (Ukraine)." Wiener Slawistischer Almanach, vol. 83, 2019, pp. 163-82.

---. 'Ukrainsko-russkaia smeshannaia rech' 'surzhik' v sisteme vzaimodeistviia ukrainskogo i russkogo iazykov.” Slověne, vol. 4, no. 2, 2015, pp. 211-46.

---. "Zwischen Ukrainisch und Weißrussisch: nordukrainische (polessische) Übergangsdialekte des linken Ufers." Wiener Slawistischer Almanach, vol. 72, 2013, pp. 35-54.

Krueger, R. A. Focus Groups: A Practical Guide for Applied Research. 3rd ed., Sage, 2000.

Preston, Dennis R. Handbook of Perceptual Dialectology. John Benjamins, 1999.

Smithson, J. "Focus Groups." The Sage Handbook of Social Research Methods, edited by Pertti Alasuutari et al., Sage, 2008, pp. 357-70. 